\title{
Pemberdayaan Masyarakat dalam Penanganan Pandemic Covid-19 Melalui Penerapan Alat Respira PAPR
}

\author{
Andi Muh Asrul Irawan', A Mukramin Yusuf ${ }^{1}$, Sarah Giovani ${ }^{2}$, Hidayat Yorianta \\ Sasaerila $^{3}$, Ahmad Juang Pratama ${ }^{4}$, Budi Aribowo ${ }^{4}$, Hanny Nurlatifah ${ }^{5}$ \\ ${ }^{\text {I}}$ Program studi Gizi, Fakultas Sains dan Teknologi, Universitas Al Azhar Indonesia \\ ${ }^{2}$ Program studi Teknologi Pangan, Fakultas Sains dan Teknologi, Universitas Al Azhar Indonesia \\ ${ }^{3}$ Program studi Biologi, Faklutas Sains dan Teknologi, Universitas Al Azhar Indonesia \\ ${ }^{4}$ Program studi Teknik Industri, Fakultas Sains dan Teknologi, Universitas Al Azhar Indonesia \\ ${ }^{5}$ Program studi Manajemen, Fakultas Ekonomi dan Bisnis, Universitas Al Azhar Indonesia \\ Kompleks Masjid Agung Al Azhar. Jalan Sisingamangaraja, Kebayoran Baru, Jakarta Selatan 12110 \\ Email Penulis Korespondensi: sarah.giovani@uai.ac.id
}

\begin{abstract}
The masks that are available and used by health workers today must be worn in layers and make it uncomfortable to wear for a long time, with these problems, personal protective equipment (PPE) is needed that is safe and comfortable to use. Based on the results of the discussion, it is known that the partner's problems are the lack of special PPE for doctors and other health workers who directly treat Covid 19 patients and most of them use disposable masks, as well as the lack of adequate and comfortable PPE for doctors or nurses who are elderly, who are forced to stop doing so. services due to lack of personal protective equipment. The solution provided by Al Azhar University Indonesia is to make and distribute PPE tools that can reduce the use of single-use masks, and the tools that are made and distributed must have good comfort and safety, especially for elderly health workers. This program includes tool preparation, distribution and evaluation. The result of the solution provided is that Al Azhar University has developed a product from the results of the research, namely Respira PAPR V.1"to reduce the use of single-use masks for health workers in hospitals and partner agencies. Based on the evaluation results, this product provides a sense of security and comfort for its users, especially for elderly health workers. The number of PAPR products distributed is 30 units in six hospitals and health agencies. In general, the product Respira PAPR V.1 can be accepted by partners and can be used by partners in health services. Suggestions for the next program is that this Respira PAPR V.1 product can be developed to increase the comfort of use, especially in terms of design and features.
\end{abstract}

Keywords: PPE, PAPR, Product, Hospital, Mask

\begin{abstract}
Abstrak
Masker yang tersedia dan digunakan oleh tenaga kesehatan saat ini harus dipakai berlapis- lapis dan membuat tidak nyaman bila dipakai dalam waktu yang lama, dengan permasalahan tersebut maka diperlukan alat perlindungan diri (APD) yang aman sekaligus nyaman digunakan. Berdasarkan hasil diskusi diketahui permasalahan mitra adalah kurangnya APD khusus bagi dokter dan tenaga kesehatan lainnya yang secara langsung menangani pasien Covid 19 dan sebagian besar menggunakan masker sekali pakai, serta kurangnya APD yang memadai dan nyaman bagi dokter atau perawat yang berusia lanjut, yang terpaksa berhenti melakukan layanan karena kurangnya peralatan pelindung diri. Solusi yang diberikan Universitas Al Azhar Indonesia adalah membuat dan mendistribusikan alat APD yang dapat mengurangi penggunaan masker sekali pakai, dan alat yang dibuat dan didistribusikan harus memiliki kenyamanan dan keamanan yang baik terutama pada
\end{abstract}


tenaga kesehatan yang berusia lanjut. Program ini meliputi persiapan alat, pendistribusian dan evaluasi. Hasil dari solusi yang di berikan adalah Universitas Al Azhar telah mengembangkan produk dari hasil penelitian yaitu "Respira PAPR V.1" untuk mengurangi penggunaan masker sekali pakai pada tenaga kesehatan di rumah sakit dan instansi Mitra. Berdasarkan hasil evaluasi, produk ini memberikan rasa aman dan nyaman pada penggunanya terutama pada tenaga kesehatan yang berusia lanjut hal ini. Jumlah Produk PAPR yang didistribusikan sebanyak 30 unit di enam rumah sakit dan instansi kesehatan. Secara umum produk "Respira PAPR V.1" dapat diterima oleh mitra dan dapat dimanfaatkan mitra dalam pelayanan kesehatan. Saran untuk program selanjutnya adalah produk "Respira PAPR V.I" ini dapat dikembangkan untuk meningkatkan kenyamanan penggunaan terutama pada desain dan fitur-fitur.

\section{Kata kunci: APD, PAPR, Produk, Rumah sakit, Masker}

\section{PENDAhUluan}

Pandemi Virus Covid 19 hampir 3 tahun kita jalani sejak diumumkan kasus pertama pada Maret 2020. Meskipun jumlah kasus sudah melandai namun pandemi belum selesai dan masih harus terus diwaspadai. Untuk penangganan Covid-19 masih dibutuhkan sarana dan prasarana kesehatan yang baik, dengan tenaga kesehatan yang memadai.

Tingginya jumlah tenaga kesehatan yang gugur pada saat penanganan pandemi menjadi catatan tersendiri karena pada saat itu Indonesia berada di jajaran negara dengan angka kematian tenaga kesehatan yang terbesar di dunia. Penyebab tingginya tingkat kematian tenaga kesehatan adalah karena (Saputra, 2020): 1) Alat Pelindung Diri (APD) yang kurang memadai; 2) Jumlah pasien covid yang tinggi, dan tidak jelasnya OTG maupun yang bebas covid 3) Jam kerja yang tinggi, dan 4) Tenaga kesehatan mempunyai penyakit bawaan.

Jumlah dana yang dimiliki Rumah Sakit untuk hal paling mendasar seperti membeli APD yang sesuai kualitas dan kuantitas nya masih tidak mencukupi. Kebutuhan baju hazmat sangat tinggi dan tergantung setiap ruangan nya, seperti di ruang isolasi, para tenaga kesehatan dalam satu hari bisa memakai sampai 30 hazmat (Fardianto, 2021). Sebenarnya diawal pandemi, banyak sumbangan yang dilakukan oleh perusahaan, yayasan, komunitas dan perorangan untuk membagikan APD ke beberapa Rumah Sakit. Tetapi sejalan dengan menurunnya perekonomian Indonesia dan bahkan dunia, akibat tidak berjalannya fungsi-fungsi ekonomi seperti sebelum masa pandemi, jumlah donasi menurun.
Selain kebutuhan APD untuk tenaga kesehatan yang memang secara langsung menangani pasien Covid 19, sejumlah dokter dan tenaga kesehatan yang berusia lanjut terpaksa berhenti memberikan layanan karena kurangnya APD sehingga mereka memiliki resiko tinggi bila terpapar virus Covid 19. Terlebih bagi tenaga kesehatan dengan usia lanjut, diperlukan pelindung diri yang tidak hanya aman, namun juga nyaman untuk digunakan dalam waktu yang lama.

Berdasarkan hal tersebut diketahui bahwa permasalahan mitra adalah 1) Kurangnya APD khusus bagi dokter dan tenaga kesehatan lainnya yang secara langsung menangani pasien Covid 19, dan sebagian besar menggunakan masker sekali pakai, 2) Kurangnya APD yang memadai dan nyaman bagi dokter atau perawat (pasien umum) yang berusia lanjut, yang terpaksa berhenti melakukan layanan karena kurangnya peralatan pelindung diri. Meskipun tidak menangani langsung pasien Covid 19, namun tenaga kesehatan dengan usia lanjut memiliki resiko tinggi bila terpapar.

Untuk mengatasi masalah hal tersebut solusi yang berikan Universitas Al Azhar Indonesia adalah 1) membuat dan mendistribusikan alat APD yang dapat mengurangi penggunaan masker sekali pakai, dan 2) Alat yang dibuat dan distribusikan harus memiliki kenyamanan dan keamanan yang baik terutama pada tenaga kesehatan yang berusia lanjut.

Universitas Al Azhar Indonesia (UAI) memiliki alat Powered Air Purifier Respirator (PAPR) merupakan pengembangan dari hasil penelitian dosen di UAI yang diberi nama LCC Respira PAPR v1.0. Alasan dipilih alat ini karena dapat berfungsi sebagai pelindung hidung dan mulut bagi tenaga kesehatan, sekaligus mampu memberikan aliran oksigen yang sehat dan bersih dari mikroorganisme 
termasuk virus COVID-19. Dalam segi kelayakan alat ini telah mendapat sertifikasi dari BPFK dan telah mendapat izin produksi dan dalam proses akhir validasi izin edar.

\section{METODE PELAKSANAAN}

Program ini merupakan bantuan dalam penanganan pandemi dengan memberikan bantuan alat PAPR kepada rumah sakit mitra untuk digunakan oleh para tenaga medis dalam menangani pasien COVID-19. Program akan melibatkan 5 rumah sakit mitra dan 1 dinas kesehatan yang masing-akan diberikan 5-6 unit alat PAPR sehingga total jumlah PAPR yang diberikan adalah 30 unit. Kegiatan dilaksanakan melalui empat tahapan yaitu tahapan persiapan, pelaksanaan, monitoring dan evaluasi dan pembuatan laporan akhir dan publikasi. Tahapan pelaksanaan dapat dilihat pada Gambar 1 berikut:

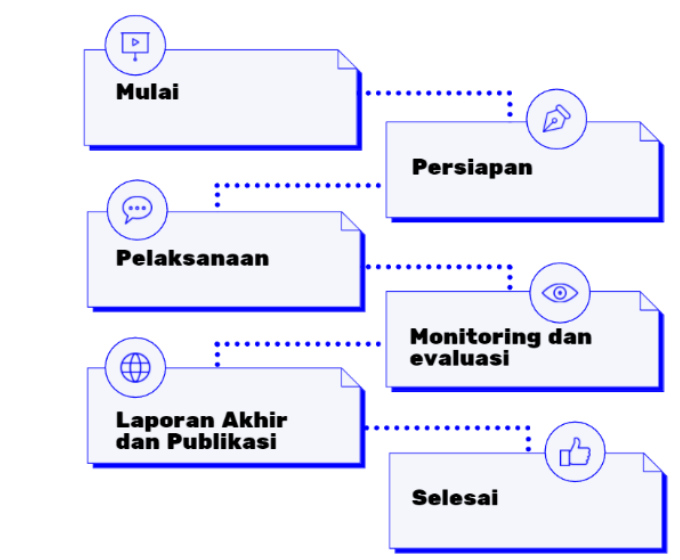

Gambar 1. Tahapan Pelaksanaan Kegiatan

\section{a) Persiapan}

Tahapan persiapan meliputi diskusi dan musyawarah dengan mitra terkait masalah yang dihadapi dan mempersiapkan alat PAPR yang akan diberikan yaitu berjumlah 30 unit. Menyiapkan tim lapangan yang membagikan alat, melakukan pelatihan penggunaan alat dan untuk melaksanakan survei. Dari kegiatan ini diharapkan alat PAPR yang telah siap untuk dibagikan beserta tim lapangan yang akan membagikan.

\section{b) Pelaksanaan}

Pelaksanaan akan dibagi menjadi tiga tim lapangan yang masing-masing tim akan mengunjungi rumah sakit mitra, tim terdiri dari mahasiswa dan dosen. Tugas dari tim lapangan membagikan alat, melakukan pelatihan penggunaan dan memberikan kuesioner secara online kepada mitra.

c) Monitoring dan Evaluasi (Monev)

Monev dilaksanakan dalam rangka mengukur keberhasilan program dengan menganalisis hasil survei.

\section{d) Laporan dan Publikasi}

Laporan dampak program pengabdian kepada masyarakat yang berupa artikel yang diterbitkan pada jurnal atau prosiding (conference) dan video yang berdurasi 15 menit. Hasil survei serta publikasi di media massa.

\section{Waktu dan Tempat Pelaksanaan}

Program dilaksanakan selama 3 minggu, yaitu pada tanggal 12 sampai dengan 30 Desember 2021. Penyerahan PAPR dilakukan di enam rumah sakit mitra yaitu RS Darurat Wisma Atlet, RSUD Cibinong, RS Bhineka Bakti Husada, RS Pertamina dan Dinkes Depok yang secara umum melingkupi area Jabodetabek.

\begin{abstract}
Alat dan Bahan:
Alat yang dapat digunakan adalah Powered Air Purifying Respirator (PAPR) karena dapat berfungsi sebagai pelindung hidung dan mulut bagi tenaga kesehatan, sekaligus mampu memberikan aliran oksigen yang sehat dan bersih dari mikroorganisme termasuk Corona Virus. Akan tetapi alat ini relatif mahal harganya. Solusi yang diberikan tim UAI adalah melakukan reverse engineering dari PAPR yang sudah ada dengan membuat PAPR yang "low budget" yaitu Low Cost Comfortable Respirator (LCCRespiraV.01) tanpa mengurangi sisi fungsional dan safety alat yang sudah ada.
\end{abstract}

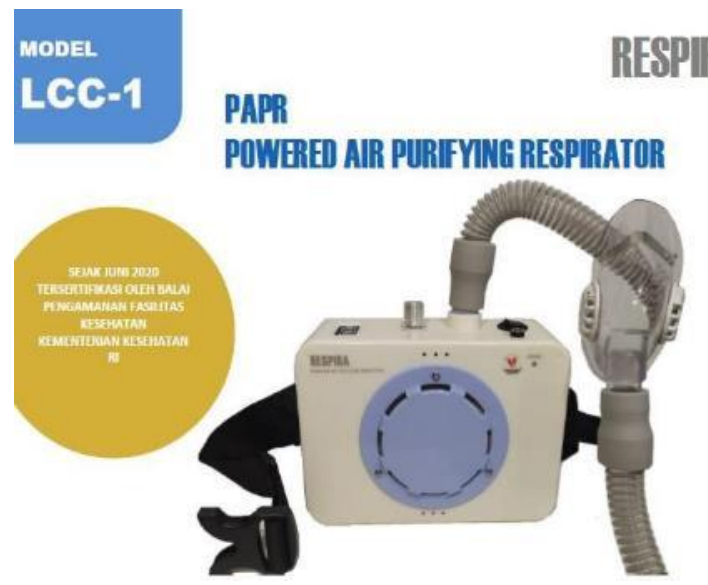

Gambar 2. LCC Respira PAPR V.1 
Alat terdiri atas pelindung muka, masker dengan selang yang terhubung dengan perangkat filter dan elektronik. Bagian masker dilengkapi dengan HEPA filter (atau filter lainnya sesuai dengan kebutuhan), sehingga dapat menyaring partikel mikro termasuk virus dan tidak pengap bagi pengguna.

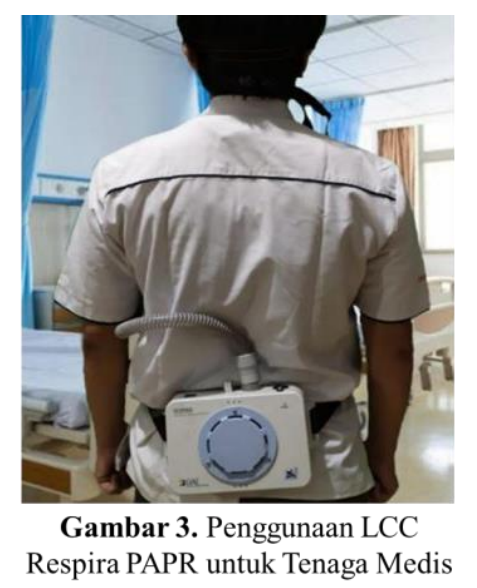

Alat ini aman untuk digunakan oleh tenaga medis karena pada bagian masker dilengkapi lapisan filter yang dapat diganti-ganti. Udara bersih dipompakan ke dalam masker untuk memudahkan pernapasan

Bagian elektronik terdiri dari motor listrik sederhana yang memungkinkan udara dari luar dipompa dan di filter. Kontrol elektrik ditanam pada alat ini agar perputaran blower dapat diatur sesuai dengan kebutuhan, sehingga memungkinkan durasi pemakaian baterai yang lebih lama. Secara lengkap alat ini dapat digunakan dalam jangka waktu sekitar 4-8 jam. Alat ini dapat diperoleh dengan biaya relatif murah. Spesifikasi alat dapat dilihat pada Tabel 1 berikut:

Tabel 1. Spesifikasi LCC Respira

\begin{tabular}{cl}
\hline Komponen & \multicolumn{1}{c}{ Spesifikasi } \\
\hline Air flow & $7-15 \mathrm{LPM}$ \\
& HEPA atau \\
& Particulate \\
& filter \\
& Material: \\
& polypropylene \\
Filter & Filter \\
& effectivity: \\
& $99,97 \%$ \\
& $\mathrm{ABS}$ \\
Blower & $230 \mathrm{~V}-50 \mathrm{~Hz}$ \\
Power rating & $10^{\circ} \mathrm{C}-40^{\circ} \mathrm{C}$, \\
Operating
\end{tabular}

\begin{tabular}{cl}
\hline Komponen & \multicolumn{1}{c}{ Spesifikasi } \\
\hline temperature/humidity & $30 \%-80 \% \mathrm{RH}$ \\
Storage & $-20^{\circ} \mathrm{C}-55^{\circ} \mathrm{C}$, \\
temperature/humidity & $10 \%-85 \% \mathrm{RH}$ \\
Berat komponen masker & $150 \mathrm{gr}$ \\
\hline
\end{tabular}

\section{HASIL DAN PEMBAHASAN}

Hasil analisis deskriptif pada Tabel 2 menunjukkan distribusi karakteristik mitra berdasarkan jenis kelamin, lama kerja, umur, dan instansi.

Mitra didominasi oleh jenis kelamin perempuan yang mencapai $67 \%$ dari total mitra dibandingkan dengan mitra laki-laki sebesar 33\%. Tabel 2 menunjukkan bahwa sebesar 92\% telah bekerja lebih dari 5 tahun dan hanya $8 \%$ yang bekerja antara 1 hingga 3 tahun.

Tabel 2. Distribusi Karakteristik mitra

\begin{tabular}{|c|c|c|}
\hline Karakteristik & $\mathrm{n}$ & $\%$ \\
\hline \multicolumn{3}{|l|}{ Jenis Kelamin } \\
\hline Laki-laki & 4 & $33 \%$ \\
\hline Perempuan & 8 & $67 \%$ \\
\hline \multicolumn{3}{|l|}{ Lama Kerja } \\
\hline 1-3 Tahun & 1 & $8 \%$ \\
\hline$\geq 5$ Tahun & 11 & $92 \%$ \\
\hline \multicolumn{3}{|l|}{ Umur } \\
\hline 21-35 Tahun & 4 & $33 \%$ \\
\hline 36-55 Tahun & 8 & $66 \%$ \\
\hline \multicolumn{3}{|l|}{ Unit Pelayanan } \\
\hline Direktur & 1 & $8 \%$ \\
\hline Dokter & 2 & $17 \%$ \\
\hline Perawat & 5 & $42 \%$ \\
\hline Struktural & 4 & $33 \%$ \\
\hline Total & 12 & $100 \%$ \\
\hline
\end{tabular}

Perbandingan proporsi kelompok umur antara 21-35 tahun dan 36-55 tahun terlihat jauh dengan kisaran 33\% dan 66\%. Dari Tabel 2 dapat disimpulkan kelompok umur 36-55 tahun merupakan kelompok yang dominan. Sebagian besar mitra merupakan tenaga perawat yaitu $42 \%$ dan struktural (Kabid Yankes, Koordinator program dan pengelola rujukan) sebanyak 33\% 


\section{Penggunaan Jenis APD Masker Sebelum Penggunaan Produk PAPR}

Dalam rangka mencegah penularan virus COVID-19, maka Organisasi Kesehatan Dunia (World Health Organization/WHO) terus menganjurkan agar tenaga kesehatan yang memberikan layanan kepada pasien suspect atau terkonfirmasi COVID-19 memakai masker atau respirator selain APD yang merupakan bagian dari kewaspadaan standar, droplet (percikan), dan kontak. Respirator, N95 atau standar FFP2 atau FFP3/setara digunakan apabila prosedur yang dilakukan berisiko terpapar aerosol

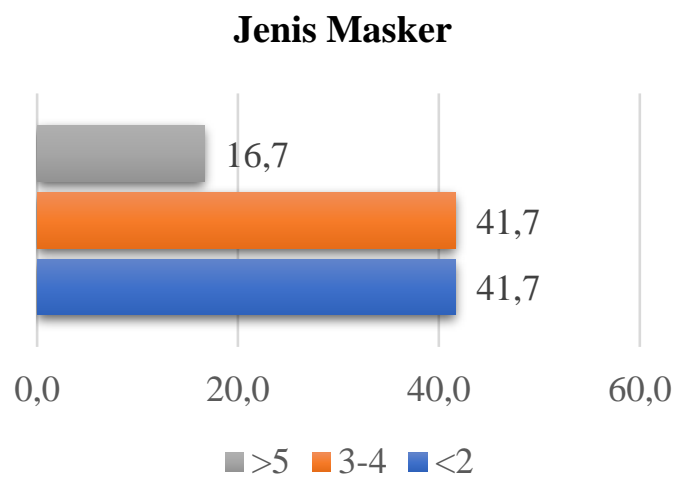

Gambar 4. Jenis Masker yang digunakan Mitra

Masker medis dapat digunakan untuk prosedur pelayanan kesehatan lain yang tidak berisiko terpapar aerosol. Respirator dapat juga digunakan oleh tenaga kesehatan saat memberikan perawatan kepada pasien COVID19 di lingkungan lain jika respirator tersedia dalam jumlah banyak dan biaya tidak menjadi masalah (WHO,2020).

Diketahui pada Gambar 4 bahwa mitra menggunakan jenis masker sebelum penggunaan PAPR (1) < 2 jenis masker sebanyak $41,7 \%$ mitra (2) 3 hingga 4 jenis masker sebanyak $41,7 \%$ mitra (3) $>5$ jenis masker sebanyak 16,7\% mitra. Jenis masker yang digunakan mitra sebelum PAPR diantaranya adalah masker surgical, masker KN95, masker P, masker N95, dan face shield.

Menurut Tirupatih et all (2020) menyatakan bahwa masker N95 digunakan oleh semua tenaga kesehatan yang melakukan kontak dengan pasien COVID-19. Namun ketika terjadi kekosongan akan masker N95, maka penggunaan masker bedah diizinkan untuk melakukan kontak dengan pasien COVID-19, dan agar lebih memaksimalkan proteksi dapat digunakan face shield.

\section{Alasan Pemilihan Produk APD}

Salah satu cara melindungi diri dari penularan COVID-19 adalah dengan menggunakan Alat Pelindung Diri (APD). Beberapa jenis APD yang diwajibkan atau disarankan untuk mencegah penularan COVID19 adalah masker (mask), pelindung wajah (face shield), dan sarung tangan (gloves). APD tersebut bertujuan untuk mencegah paparan virus ke dalam tubuh ataupun menularkan virus ke orang lain (Atmojo et all, 2020).

Tenaga kesehatan yang menggunakan APD masih terdapat risiko penularan virus COVID19 melalui droplet atau aerosol dari pasien yang terdapat di udara dan masuk melalui celah yang terbentuk tanpa sengaja oleh petugas kesehatan. Misal, ketika membenarkan posisi, memulai posisi, menyeka keringat, dan membuka baju pelindung (Theopilus et all).

Pada Gambar 5 didapatkan alasan mitra memilih produk APD. Diketahui pada Gambar 5 bahwa empat alasan terbanyak mitra yakni (1) sebanyak $41,7 \%$ mitra menyatakan kenyamanan produk, (2) sebanyak 33,3\% menyatakan ketersediaan produk, (3) sebanyak $16,7 \%$ menyatakan harga produk, (4) sebagian kecil mitra sebesar $8,3 \%$ menyatakan lainnya

\section{Alasan Pemilihan Produk APD}

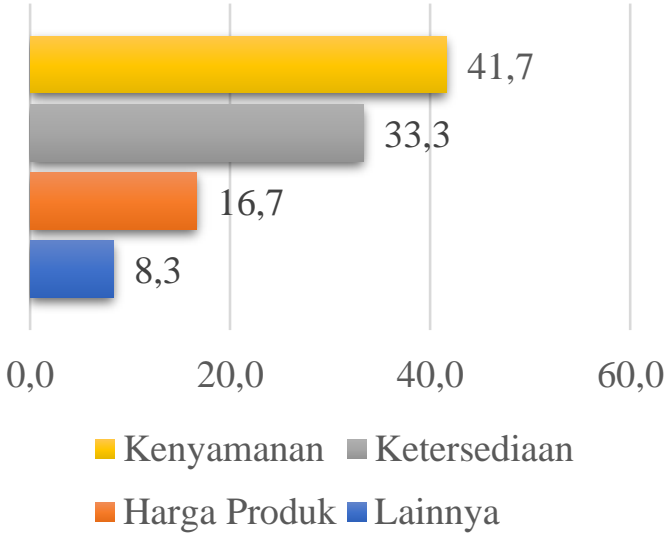

Gambar 5. Alasan memilih Produk APD

Beberapa fenomena terkait risiko APD, seperti desain tidak ergonomis, pemakaian berlebihan menimbulkan sakit di beberapa bagian tubuh, penyimpanan dan pembuangan yang membahayakan, dan lainnya. Maka, kenyamanan APD yang membuat tenaga kesehatan terhindar dari masuknya virus COVID-19 ke dalam tubuh sangat diperlukan?

Beberapa permasalahan dalam penanganan pandemi COVID-19 dialami oleh rumah sakit yang akan menjadi mitra UAI, yakni RS 
Darurat Wisma Atlet, RSUD Cibinong, RS Pertamina Pusat (RSPP), Dinkes Depok dan RS Bhineka Bakti Husada diantaranya yaitu (1) diperlukan APD yang memadai khususnya bagi para tenaga kesehatan. Saat ini sebagian besar tenaga kesehatan menggunakan masker N95 dan baju APD sebagai perlindungan dari virus COVID-19. (2) Harga APD yang relatif terjangkau sangat diperlukan. Jumlah dana yang dimiliki Rumah Sakit untuk membeli APD yang sesuai kualitas dan kuantitas nya masih tidak mencukupi. Ketersediaan APD yang memadai membuat tenaga kesehatan melaksanakan kewaspadaan standar dengan baik.

\section{Kesan Penggunaan Produk PAPR}

Gambar 6 di bawah dapat diketahui kesan mitra terhadap penggunaan produk PAPR. Sebanyak $67 \%$ mitra setuju terhadap kualitas produk secara keseluruhan. Diketahui pada Gambar 6 bahwa sebanyak $83 \%$ mitra setuju terhadap keandalan produk secara keseluruhan. Hampir semua mitra sebanyak 92\% setuju terhadap kegunaan produk secara keseluruhan

\section{Kesan Penggunaan Produk PAPR}

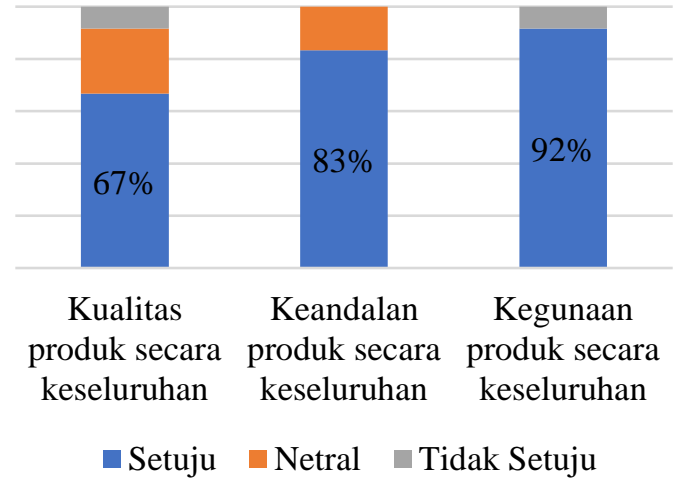

. Gambar 6. Kesan Penggunaan Produk PAPR

LCC Respira v1.0 berfungsi sebagai pelindung hidung dan mulut bagi tenaga kesehatan, sekaligus mampu memberikan aliran oksigen yang sehat dan bersih dari mikroorganisme termasuk virus COVID-19. Berdasarkan hasil diskusi dengan mitra UAI, produk PAPR mudah penggunaannya dan fungsional, namun diharapkan ada perbaikan desain produk lebih sederhana dan minimalis.

\section{Rasa Aman dan Nyaman Produk PAPR
Rasa Aman dan Nyaman Produk PAPR

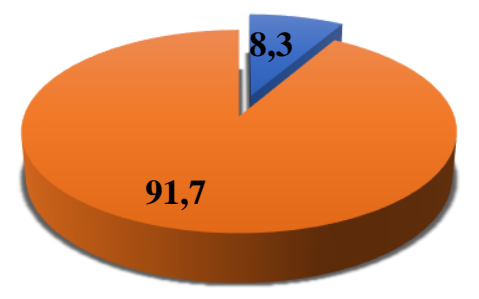

Tidak $\square$ Ya

Gambar 7. Rasa Aman dan Nyaman Produk PAPR

Pada Gambar 7 menunjukkan bahwa sebanyak 91,7\% mitra menyatakan produk PAPR dapat memberikan rasa aman dan nyaman. Hal ini menunjukkan bahwa mitra nyaman menggunakan produk PAPR ketika bekerja terutama saat menangani langsung pasien COVID-19 karena merasa aman. Produk PAPR ini berdasarkan hasil diskusi dengan Rumah Sakit yang menjadi mitra UAI, telah digunakan pada saat proses operasi, di ruang UGD, bahkan digunakan oleh Dokter Gigi dan THT.

\section{Evaluasi Produk PAPR}

Pada Gambar 8 menunjukkan bahwa sebanyak $83 \%$ mitra menyatakan bahwa produk PAPR memuaskan. Diketahui pada Gambar 8 bahwa sebanyak $67 \%$ mitra menyatakan bahwa produk PAPR menyenangkan. Hampir semua mitra sebesar $92 \%$ menyatakan bahwa produk PAPR lebih bermanfaat dibandingkan produk lain

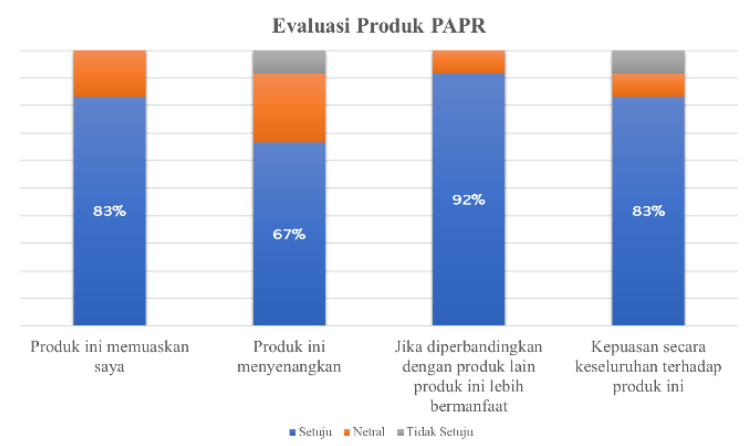

Gambar 8. Evaluasi Produk PAPR 
Andi Muh Asrul Irawan, A Mukramin Yusuf, Sarah Giovani, Hidayat Yorianta Sasaerila, Ahmad Juang Pratama, Budi Aribowo, Hanny Nurlatifah $R$

Secara keseluruhan, sebanyak $83 \%$ mitra merasa puas terhadap produk PAPR. Namun, ada fitur yang perlu diperbaiki untuk meningkatkan kenyamanan penggunaannya dan juga memerlukan uji klinis, sehingga dapat direkomendasikan kepada pasar yang lebih luas.

\section{SIMPULAN DAN SARAN}

Kegiatan pengabdian masyarakat melibatkan instansi dan rumah sakit di wilayah Jabodetabek. Hasil dari solusi yang di berikan adalah Universitas Al Azhar telah mengembangkan produk dari hasil penelitian yaitu PAPR Respira V.1 untuk mengurangi penggunaan masker sekali pakai pada tenaga kesehatan di Rumah sakit dan instansi Mitra.

Berdasarkan hasil evaluasi produk ini memberikan rasa aman dan nyaman pada penggunanya terutama pada tenaga kesehatan yang berusia lanjut hal ini. Jumlah Produk PAPR yang didistribusikan sebanyak 30 unit.

Secara umum produk Respira PAPR V.1 dapat diterima oleh mitra dan dapat dimanfaatkan mitra dalam pelayanan kesehatan. Saran untuk program selanjutnya adalah produk Respira PAPR V.I ini dapat dikembangkan untuk meningkatkan kenyamanan penggunaan terutama pada desain dan fitur-fitur. Selain itu, diharapkan setiap fasilitas kesehatan dapat memanfaatkan produk Respira PAPR V.1 dalam pelayanan kesehatan terutama fasilitas kesehatan yang menangani Pasien Covid-19

\section{UCAPAN TERIMAKASIH}

Atas publikasi ini penulis mengucapkan Terima kasih kepada Ditjen Dikti Ristek atas bantuan pendanaan Program Penelitian Kebijakan Merdeka Belajar Kampus Merdeka dan Pengabdian kepada Masyarakat Berbasis Hasil Penelitian Perguruan Tinggi Swasta Tahun 2021.

\section{DAFTAR PUSTAKA}

Saputra. A, (2020), "Nakes di Indonesia Berguguran Akibat COVID-19," Gridhealth, [Online]. Available: https://health.grid.id/read/352325367/181-

nakes-di- indonesia-berguguran-akibatcovid-19-rupanya-ada-risikoburnout?page $=$ all.

Fardianto. F, (2021), "Pasien COVID-19 Antre, Ruang Isolasi RS Wongsonegoro Semarang Penuh," IDN Times, [Online]. Available: https://jateng.idntimes.com/news/jateng/fari z-fardianto/pasien-covid-19-antre-ruangisolasi-rs-wongsonegoro-semarang-penuh.

WHO. (2020). Penggunaan masker dalam konteks COVID-19.

Tirupathi, R. et al. (2020). Comprehensive Review of mask utility and challenges during the COVID-19 pandemic. Infezioni in Medicina, 28, pp. 57-63.

Atmojo, J., Akbar, P., Kuntari, S., Yulianti, I., \& Darmayanti, A. (2020). Definition and The Most Active Severe Acute Respiratory Syndrome Coronavirus 2 (Sars-Cov-2) or Covid-19. Jurnal Pendidikan Kesehatan (EJournal), 9(1), 57-64.

Theopilus, Y., Thedy, Y., Clara, T., Johanna, R. (2020). Analisis Risiko Produk Alat Pelindung Diri (APD) Pencegah Penularan COVID-19 untuk Pekerja Informal di Indonesia. Jurnal Rekayasa Sistem Industri, 9(2), 115-133. 